\title{
Enantiospecific formal total synthesis of homogynolide-A
}

\author{
A. Srikrishna* and T. Jagadeeswar Reddy \\ Department of Organic Chemistry, Indian Institute of Science, Bangalore 560 012, India \\ E-mail: ask@orgchem.iisc.ernet.in \\ Dedicated to Professor T. R. Govindachari \\ (received 26 Apr 01; accepted 24 Jul 01; published on the web 01 Aug 01)
}

\begin{abstract}
Formal total synthesis of both enantiomers of homogynolide-A, a sesquiterpene containing an $\alpha$ spiro- $\beta$-methylene- $\gamma$-butyrolactone moiety fused to a bicyclo[4.3.0]nonane framework, is described. Thus, $(R)$-carvone was converted into both enantiomers of 3-methylcarvone 14. A reductive allylation, Wacker oxidation and intramolecular aldol condensation sequence transformed 3-methylcarvone into the hydrindanone 18. Regiospecific reduction of the enone followed by a three step degradation of the isopropenyl group converted the hydrindanone 18 into the dione 21, which on regioselective ketalisation furnished the key intermediate ketoketal 13. Methoxymethylene Wittig reaction followed by bromoacetalisation reaction transformed the ketoketal 13 into the bromoacetal 23. The 5-exo-dig radical cyclisation of the bromoacetal 23 followed by the hydrolysis and oxidation of the resultant spiroacetal 24 furnished a 1:4 mixture of the Greene's precursor ketospirolactone 12 and its spiroepimer 26.
\end{abstract}

Keywords: Homogynolide-A, reductive allylation, Wacker oxidation, intramolecular aldol condensation, Wittig reaction

\section{Introduction}

The creativity of Nature in devising varied molecular architecture is revealed through the isolation of a wide range of natural products with remarkable skeletal build-up and multifarious functionalities. Sesquiterpenes, biogenetically derived from farnesyl pyrophosphate, are assembled in acyclic, monocyclic, bicyclic, tricyclic and even tetracyclic structures containing small, medium and large rings with a wide range of functionalities. ${ }^{1}$ The great diversity in their molecular architecture has made synthesis of sesquiterpenoids a challenging and exciting area of research. $^{2}$ In 1976, Sorm and co-workers ${ }^{3}$ reported isolation of homogynolides-A 1 and B 2 along with bakkenolide-A 3 from Homogyne alpina. (L.) CASS. Homogynolides, belong to a small group of sesquiterpenes, bakkanes $\mathbf{4}$, which are biogenetically derived from eremophilanes 5 , containing a novel $\alpha$-spiro- $\beta$-methylene- $\gamma$-butyrolactone moiety spirofused to hydrindane framework. ${ }^{4}$ The homogynolides-A and $\mathrm{B}$ were found to possess antifeedant activity against certain types of beetle adults (Sitophilus granarius, Tribolium confusum) and larvae 
(Trogoderma granarium, Tribolium confusum). ${ }^{5}$ The structures of homogynolides-A 1 and B 2 were established as the angelyl ester of 2-hydroxybakkenolide-A and tiglyl ester of 3-hydroxybakkenolide-A, respectively, via chemical degradation and spectral comparison with other bakkenolides. The unusual structural features of homogynolides coupled with their associated biological activities made them attractive and challenging synthetic targets. Despite their biological properties, homogynolides and bakkenolides have received only a limited attention from synthetic chemists. ${ }^{6-9}$ Only one approach by Greene and co-workers was reported in the literature for the total synthesis of homogynolides-A and B prior to the initiation of work in our laboratory, and after the completion of our synthesis, ${ }^{9}$ Mori and Matsushima ${ }^{7 \mathrm{c}}$ have reported the total synthesis of (-)-homogynolide-A.<smiles>C=C1COC(=O)[C@]12C[C@H]1C[C@H](OC(=O)/C(C)=C\C)C[C@H](C)[C@]1(C)C2</smiles>

Homogynolide-A 1

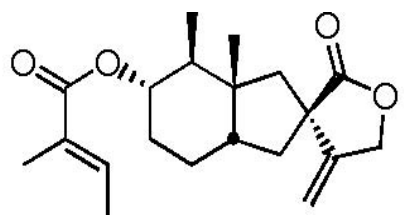

Homogynolide-B 2

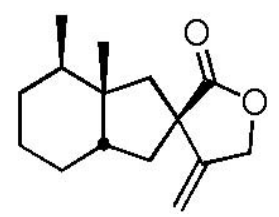

Bakkenolide-A 3

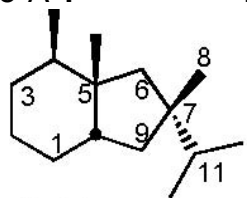

Bakkane 4<smiles>CC(C)C1CCC2CCC[C@@H](C)[C@]2(C)C1</smiles>

Eremophilane $\mathbf{5}$

In our laboratory, a general, radical cyclisation based methodology ${ }^{10}$ was developed for the construction of $\alpha$-spiro- $\beta$-methylene- $\gamma$-butyrolactones starting from cyclic ketones, Scheme 1. Methoxymethylene Wittig reaction of a cyclic ketone $\mathbf{6}$ followed by bromoacetalisation of the resultant enol ether 7 with NBS and propargyl alcohol generates the bromoacetal 8 . The 5-exodig-radical cyclisation of the bromoacetal $\mathbf{8}$ followed by hydrolysis and oxidation of the resultant spiroacetal 9 furnishes the spirolactone 10. Based on this methodology, in continuation of our work on the synthesis of $\left( \pm\right.$-homogynolide-B, ${ }^{8 b}$ we have achieved a formal total synthesis of both enantiomers of homogynolide-A, ${ }^{9}$ starting from $(R)$-carvone 11, and herein we describe the details of these investigations.<smiles>O=C1CC[C]CC1</smiles>

6

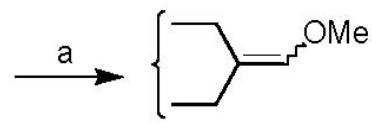

7

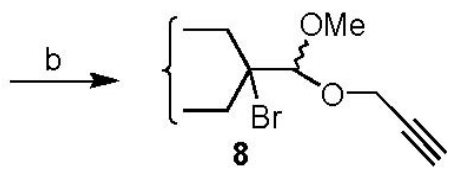

8

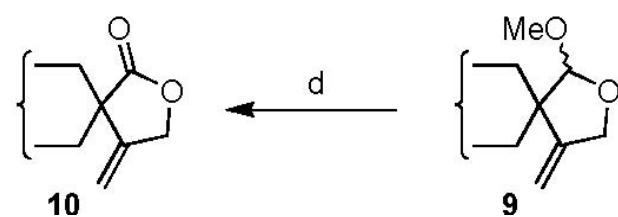

(a) $\quad \mathrm{Ph}_{3} \mathrm{P}=\mathrm{CHOMe}$; (b) NBS, $\mathrm{HC} \equiv \mathrm{CCH}_{2} \mathrm{OH}$; (c) ${ }^{\mathrm{n}} \mathrm{Bu}_{3} \mathrm{SnH}$, AIBN; (d) Jones reagent.

\section{Scheme 1}

The ketospirolactone 12, the penultimate precursor in Greene's ${ }^{7 a}$ synthesis of (-)homogynolide-A was identified as the target molecule, whose retrosynthetic analysis is depicted in Scheme 2. Based on the radical cyclisation based methodology ( $c a$ Scheme 1), the ketoketal $\mathbf{1 3}$ was readily recognized as the key intermediate, and $(R)$-carvone $\mathbf{1 1}$ was chosen as the chiral 
source. The isopropenyl group in carvone was readily recognised as a masked hydroxy group required for homogynolide-A. Since $(R)$-carvone $\mathbf{1 1}$ can be converted into either enantiomer of 3-methylcarvone 14 with equal efficiency (eqn. 1), ${ }^{11}$ it was contemplated to use 3-methylcarvone as the starting material for the synthesis of both enantiomers of homogynolide-A. A reductive alkylation methodology for the generation of the secondary and tertiary methyl groups, and a Wacker reaction mediated cyclopentannulation methodology were envisaged for the generation of the hydrindanone 15.

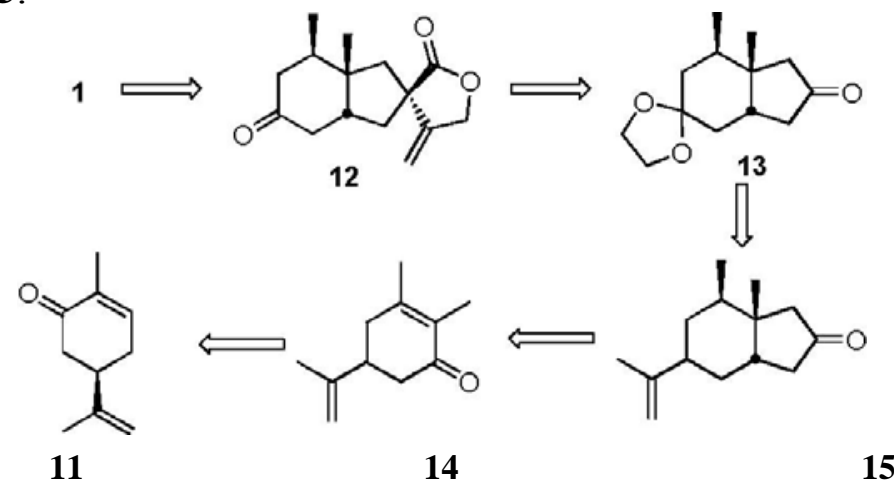

Scheme 2

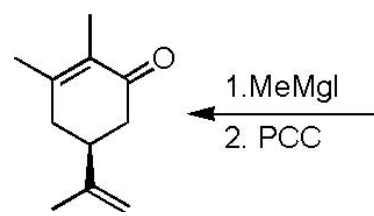

$(S)-14$

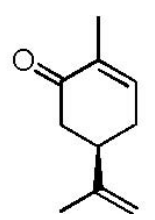

$(R)-11$

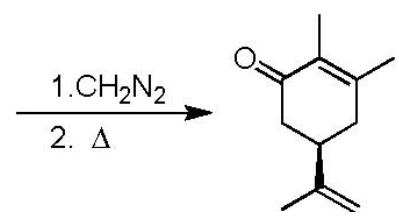

$(R)-14$

To begin with, $(R)$-carvone 11 was converted into both $(R)$ - and (S)-enantiomers of 3methylcarvone 14, employing 1,3-dipolar cycloaddition of diazomethane followed by thermolysis of the resulting pyrazoline derivative, and regioselective 1,2-addition of methylmagnesium iodide followed by oxidation of the resultant tertiary alcohol, respectively. ${ }^{11}$ The synthesis was carried out starting from both enantiomers, but for brievity the sequence employing (R)-enantiomer of 3-methylcarvone (-)-14 is described here, Schemes 3 and 4. For the simultaneous generation of the secondary and tertiary methyl groups, reductive allylation of 3methylcarvone 14 was explored. Thus, reduction of $(R)$-3-methylcarvone 14 using lithium, liquid ammonia and tertiary butyl alcohol followed by quenching the intermediate enolate with allyl bromide generated a mixture of epimers 16, whose separation was found to be difficult and hence proceeded further. The regiospecificity of Wacker reaction ${ }^{12}$ for the oxidation of mono substituted olefins was exploited for the conversion of the allyl into an acetonyl group for the generation of a 1,4-diketone. Thus, reaction of an epimeric mixture of the allyl compound $\mathbf{1 6}$ with a catalytic amount of palladium chloride and cuprous chloride in dimethylformamide and water in an oxygen atmosphere (using a balloon) furnished a $\approx 2: 1$ mixture of the diketones 17a and $\mathbf{1 7 b}$, which were separated by column chromatography on silica gel. The structures of the diones 17a and 17b were established from their interrelated spectral data (IR, ${ }^{1} \mathrm{H}$ and ${ }^{13} \mathrm{C}$ NMR). The stereochemistry of the secondary methyl group in the products was assigned as cis with respect to the isopropenyl group based on the thermodynamic considerations in the first step of the reductive allylation reaction. The stereochemistry at the $\alpha$-carbon in the major product 17a was assigned based on the preferential approach of the electrophile trans to the secondary methyl 
group in the alkylation step. The structures were confirmed by comparison of the spectral data with the other two diastereomers of the dione. ${ }^{13}$ Intramolecular aldol condensation of the dione 17a using $10 \%$ aqueous potassium hydroxide in methanol cleanly furnished the enone 18. For the conversion of the isopropenyl moiety into an acetoxy group, regioselective ozonation followed by Craigee rearrangement of the enone 18 was briefly explored. As it was found to be inefficient, regiospecific reduction of the endo cyclic olefin was addressed first, employing electron transfer methodology. Consequently, regiospecific 1,4-reduction of the enone moiety using lithium in liquid ammonia transformed the enone $\mathbf{1 8}$ into the hydrindanone $\mathbf{1 5}$ containing traces of the corresponding trans isomer. For the conversion of the isopropenyl moiety into a ketone functionality, three step sequence viz. addition of hydrogen halide, dehydrohalogenation and ozonolytic cleavage, was employed. Accordingly, addition of hydrogen bromide in ether at $0-5{ }^{\circ} \mathrm{C}$ followed by dehydrobromination of the resultant tertiary bromide 19 with DBU in benzene at $130{ }^{\circ} \mathrm{C}$ in a sealed tube transformed the hydrindanone $\mathbf{1 5}$ into the isomerised compound 20 in 89\% yield. Ozonolysis of the isopropylidene group in $\mathbf{2 0}$ in methanol-methylene chloride followed by reductive work up with triphenylphosphine furnished the dione (-)-21 in $88 \%$ yield, whose structure was established from its spectral data. The molecular ion at $\mathrm{m} / \mathrm{z} 180$ in the mass spectrum, presence of two carbonyl absorption bands at 1740 and $1710 \mathrm{~cm}^{-1}$ due to the 5- and 6-membered cyclic ketones, respectively, in the IR spectrum and absence of resonances due to the olefinic carbons in the ${ }^{13} \mathrm{C}$ NMR spectrum revealed the formation of the dione 21. In the ${ }^{1} \mathrm{H}$ NMR spectrum, presence of a singlet at $\delta 1.21$ and a doublet at 0.9 due to tertiary and secondary methyl groups, respectively, and the 11 lines ${ }^{13} \mathrm{C}$ NMR spectrum with diagnostic resonances at $\delta 215.9$ and 210.4 due to carbonyl carbons of five and six membered cyclic ketones, respectively, at 40.7 due to the quaternary carbon, at 18.7 and $16.6 \mathrm{ppm}$ due to two methyl groups confirmed the structure of the dione 21. Regioselective protection of the 6 membered ring ketone with ethylene glycol and a catalytic amount of $p$-toluenesulfonic acid (pTSA) in refluxing benzene using a Dean-Stark water separator transformed the dione 21 into the (-)-ketoketal 13 in 65\% yield, the key intermediate in the sequence, whose structure was established from its spectral data. In a similar manner, $(S)$-methylcarvone (+)-14 was transformed into the enantiomeric ketoketal $(+)-\mathbf{1 3}$.
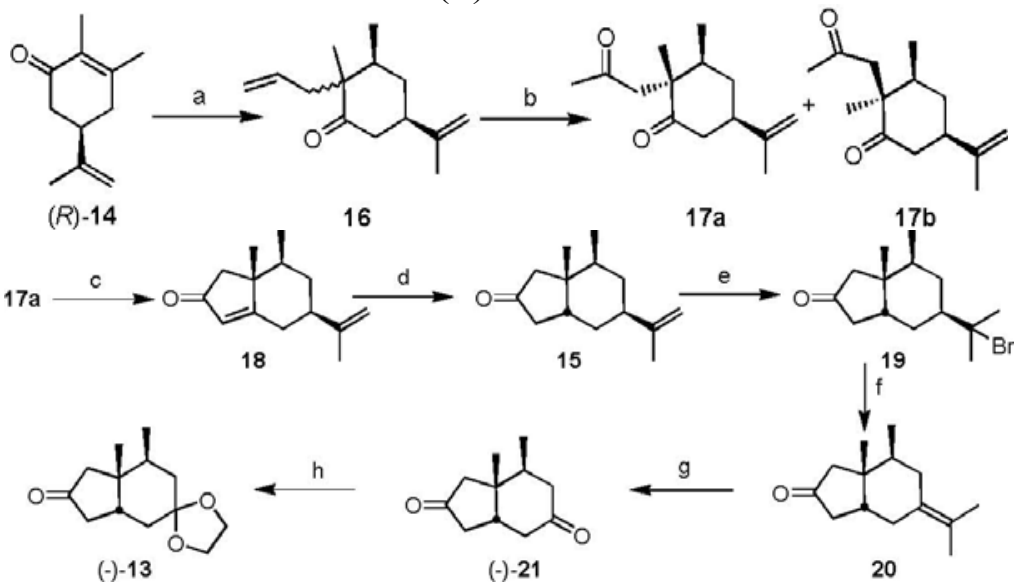

Scheme 3. (a) Li, liq. $\mathrm{NH}_{3} ; \mathrm{CH}_{2}=\mathrm{CHCH}_{2} \mathrm{Br}$; (b) $\mathrm{PdCl}_{2}, \mathrm{CuCl}, \mathrm{DMF}-\mathrm{H}_{2} \mathrm{O}, \mathrm{O}_{2}$; (c) $\mathrm{KOH}$; (d) Li, liq. $\mathrm{NH}_{3} ;$ (e) $\mathrm{HBr}(\mathrm{g})$; (f) DBU; (g) $\mathrm{O}_{3} / \mathrm{O}_{2} ; \mathrm{PPh}_{3} ;$ (h) $\left(\mathrm{CH}_{2} \mathrm{OH}\right)_{2}$, p-TSA. 


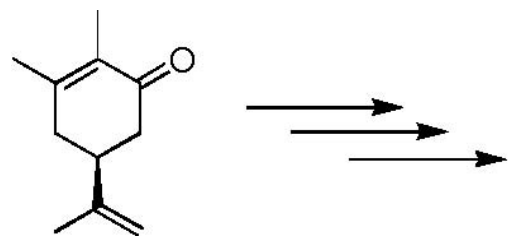

(S)-14

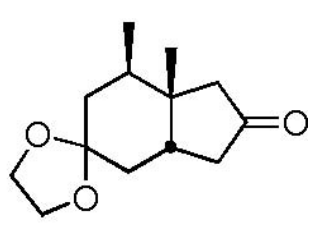

$(+)-13$

After successful synthesis of both enantiomers of the keto ketal 13, attention was then turned to the target molecule, the ketospirolactone 12, Greene's precursor of homogynolide-A, Scheme 3. Methoxymethylene Wittig reaction of the keto ketal (-)-13 with methoxymethyltriphenylphosphonium chloride and potassium tertiary amyloxide in THF furnished a 1:1 mixture of $E, Z$ isomers of the enol ether 22. A bromoacetalisation reaction ${ }^{14}$ with NBS and propargyl alcohol in methylene chloride at low temp. $\left(-50^{\circ} \mathrm{C}\right)$ transformed the enol ether 22 into a diastereomeric mixture of the bromoacetal 23. The 5-exo-dig radical cyclisation reaction of the bromoacetal 23 using an in situ generated catalytic tri-n-butyltin hydride $\left({ }^{\mathrm{n}} \mathrm{Bu}_{3} \mathrm{SnCl}-\mathrm{NaCNBH}_{3}\right)^{15}$ in the presence of a catalytic amount of AIBN in refluxing tertiary butyl alcohol furnished a diastereomeric mixture of the spiro compound 24 . Simultaneous hydrolysis of the ketal and acetal moiety in 24 using $3 \mathrm{~N} \mathrm{HCl}$ and oxidation of the resultant keto lactol 25 using PCC and silica gel furnished a ca 1:4 mixture of the spirolactone ()-12 and its spiro epimer (+)-26, which were separated by careful column chromatography on silica gel. The ${ }^{1} \mathrm{H}$ NMR (270 MHz) spectrum of the minor ketospirolactone 12 exhibited signals, identical to that of an authentic sample prepared earlier by Greene et al. The structure of the epiketospirolactone 26 was established from its spectral data. In a similar manner, the enantiomeric ketoketal $(+)-\mathbf{1 3}$ was transformed into the spirolactones $(+)-\mathbf{1 2}$ and (-)-26.

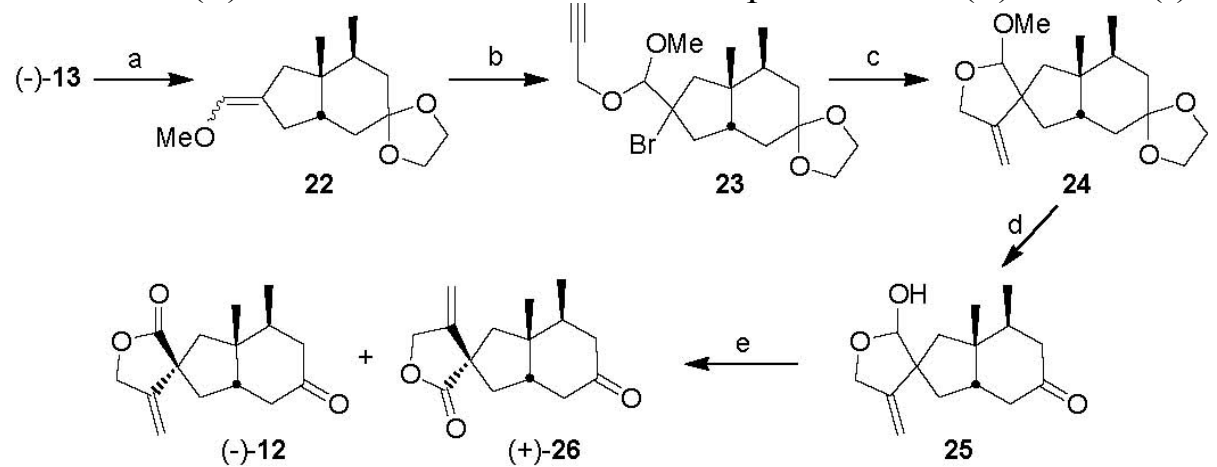

Scheme 4. (a) $\mathrm{Ph}_{3} \mathrm{P}=\mathrm{CHOMe}$; (b) $\mathrm{NBS}, \mathrm{HC} \equiv \mathrm{CCH}_{2} \mathrm{OH}$; (c) ${ }^{\mathrm{n}} \mathrm{Bu}_{3} \mathrm{SnCl}, \mathrm{NaCNBH}_{3}, \mathrm{AIBN}$; (d) $3 \mathrm{~N}$ $\mathrm{HCl}$; (e) PCC, silica gel.

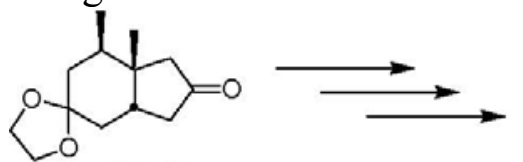

$(+)-13$

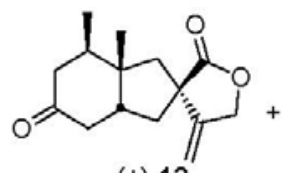

$(+)-12$

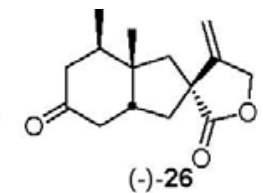

$(-)-26$

The formation of the two epimers 12 and 26 was, obviously, a consequence of the cyclisation of the radical 27 via endo or exo face of the molecule. Even though the formation of the epispirolactone 26 was not anticipated based on the homogynolide-B synthesis, ${ }^{8 c}$ recently, Greene et al. have also reported ${ }^{6 \mathrm{j}}$ a similar observation in the synthesis of one of the oxygenated bakkenolides employing a radical cyclisation strategy (Eq. 2). Since the spirolactone (-)-12 has already been transformed into (-)-homogynolide-A by Greene and coworkers, ${ }^{7 b}$ the present 
sequence constitutes a formal total synthesis of both enantiomers of homogynolide-A.
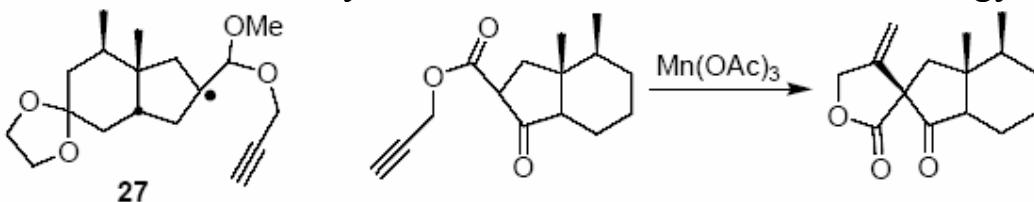

In conclusion, formal total synthesis of both enantiomers of homogynolide-A has been accomplished employing $(R)$-carvone as the source of chirality, via $(R)$ - and $(S)$-enantiomers of 3-methylcarvone 14 and the hydrindane based ketoketal 13 as the key intermediates. A radical cyclisation based methodology was exploited for the spiroannulation of a $\beta$-methylene- $\gamma$ butyrolactone for the generation of Greene's precursor for homogynolide-A.

\section{Experimental Section}

General Procedures. Melting points are recorded using a Tempo melting point apparatus in capillary tubes and are uncorrected. IR spectra were recorded on Perkin-Elmer 781 spectrophotometer. ${ }^{1} \mathrm{H}(90,200$ and $270 \mathrm{MHz})$ and ${ }^{13} \mathrm{C}$ NMR $(22.5,50$ and $100 \mathrm{MHz}) \mathrm{spectra}$ were recorded on Jeol FX90Q, Brucker ACF-200, WH-270 and AMX-400 spectrometers. The chemical shifts $(\delta \mathrm{ppm})$ and the coupling constants $(\mathrm{Hz})$ are reported in the standard fashion with reference to either internal tetramethylsilane (for ${ }^{1} \mathrm{H}$ ) or the central line $\left(77.1 \mathrm{ppm}\right.$ ) of $\mathrm{CDCl}_{3}$ (for ${ }^{13} \mathrm{C}$ ). In the ${ }^{13} \mathrm{C}$ NMR spectra off-resonance multiplicities, when recorded are given in parentheses. Low and High resolution mass measurements were carried out using a Jeol JMS-DX 303 GC-MS instrument using a direct inlet mode. Relative intensities of the ions are given in parentheses. Elemental analyses were carried out using a Carlo Erba $1106 \mathrm{CHN}$ analyzer. Optical rotations were measured using a Jasco DIP-370 digital polarimeter and $[\alpha]_{\mathrm{D}}$ values are given in the units of $10^{-1}$.deg. $\mathrm{cm}^{2} \cdot \mathrm{g}^{-1}$. Ozonolysis was carried out using a Penwalt Wallace and Tierman ozonator. Acme's silica gel (100-200 mesh), approximately 15-20 g per $1 \mathrm{~g}$ of the crude product, was used for column chromatography. All small-scale dry reactions were carried out using standard syringe-septum technique. Dry THF was obtained by distillation over sodiumbenzophenone ketyl. AIBN was recrystallised from methanol and stored in dark. $\mathrm{HBr}$ in ether was prepared by bromination of tetralin with bromine according to Vogel's procedure. $(R)$ - and $(S)$-3-methylcarvones were prepared from $(R)$-carvone as described earlier. ${ }^{11}$

$(2 R, 3 S, 5 R)$ and (2S,3S,5R)-2-Allyl-5-isopropenyl-2,3-dimethylcyclohexanones (16). To magnetically stirred ammonia (freshly distilled over sodium and $\mathrm{FeCl}_{3}, 600 \mathrm{~mL}$ ) was added lithium pieces $(500 \mathrm{mg}, 72.0 \mathrm{mmol}$ ) over a period of $5 \mathrm{~min}$. To the resultant dark blue solution was added a solution of (R)-3-methylcarvone $14(3.0 \mathrm{~g}, 18.3 \mathrm{mmol})$ and tert-BuOH (1.36 ml, $14.5 \mathrm{mmol}$ ) in $60 \mathrm{ml}$ of THF, drop wise, over a period of $25 \mathrm{~min}$. The reaction mixture was stirred for $50 \mathrm{~min}$ at the same temperature and allyl bromide $(21.45 \mathrm{~g}, 15 \mathrm{~mL}, 177 \mathrm{mmol})$ was added. The reaction mixture was slowly warmed up to RT, stirred for $6 \mathrm{~h}$, diluted with water $(30 \mathrm{~mL})$ and extracted with ether $(3 \times 20 \mathrm{~mL})$. The combined organic extract was washed with brine and dried $\left(\mathrm{Na}_{2} \mathrm{SO}_{4}\right)$. Evaporation of the solvent and purification of the residue over a silica gel column using ethyl acetate-hexane (0:100 to 1:50) as eluent furnished a 2:1 epimeric mixture 
of the allyl compound $16(2.37 \mathrm{~g}, 63 \%)$ as an oil. IR (neat): $v_{\max } 3070,1700,1640,900,890 \mathrm{~cm}^{-}$

1. ${ }^{1} \mathrm{H} \mathrm{NMR}$ (90 MHz, $\mathrm{CDCl}_{3}, 2: 1$ mixture of diastereomers): $85.50-6.00$ (1 H, m, H-2'), 4.85-5.20 (2 H, m, H-3'), $4.74\left(2 \mathrm{H}\right.$, br s, $\left.\mathrm{C}=\mathrm{CH}_{2}\right), 1.70\left(3 \mathrm{H}\right.$, s, olefinic $\left.\mathrm{CH}_{3}\right), 0.96$ and $1.04(3 \mathrm{H}, \mathrm{s}$, tert $\left.\mathrm{CH}_{3}\right), 0.93\left(3 \mathrm{H}, \mathrm{d}, \mathrm{J}=5.8 \mathrm{~Hz}\right.$, sec $\left.-\mathrm{CH}_{3}\right)$.

$(2 R, 3 S, 5 R)$ and (2S,3S,5R)-5-Isopropenyl-2,3-dimethyl-2-(2-oxopropyl)cyclohexanones (17a) and (17b). A suspension of palladium chloride (95 mg, $0.54 \mathrm{mmol}$ ) and cuprous chloride (781 $\mathrm{mg}, 7.89 \mathrm{mmol})$ in DMF $(10.5 \mathrm{ml})$ and water $(3.2 \mathrm{ml})$ was magnetically stirred in an oxygen atmosphere, created via evacuative displacement of air using an oxygen balloon, for $1 \mathrm{~h}$ at RT. A solution of the 2:1 epimeric mixture of allyl compound 16 (2.2 g, $10.67 \mathrm{mmol})$ in $3 \mathrm{ml}$ of DMF was then added, and the reaction mixture was stirred for $24 \mathrm{~h}$ at RT in the oxygen atmosphere. $3 \mathrm{~N} \mathrm{HCl}(5 \mathrm{ml})$ was added to the reaction mixture and extracted with ether $(3 \times 10$ $\mathrm{ml}$ ). The ether layer was washed with saturated aq. $\mathrm{NaHCO}_{3}$ solution followed by brine and dried $\left(\mathrm{Na}_{2} \mathrm{SO}_{4}\right)$. Evaporation of the solvent and careful chromatography of the residue over a silica gel column using ethyl acetate-hexane (1:20 to 1:5) as eluent furnished the diketones 17a (925 mg, 39\%) and 17b (475 mg, 20\%). For the major diketone (17a). $[\alpha]_{\mathrm{D}}{ }^{27}:+81.6$ (c 2.44, $\left.\mathrm{CHCl}_{3}\right)$. IR (neat): $v_{\max } 3055,1700,1640,890 \mathrm{~cm}^{-1} .{ }^{1} \mathrm{H} \mathrm{NMR}\left(90 \mathrm{MHz}, \mathrm{CDCl}_{3}\right): \delta 4.75(2 \mathrm{H}$, br $\left.\mathrm{s}, \mathrm{C}=\mathrm{CH}_{2}\right), 2.89$ and $2.47\left(2 \mathrm{H}, 2 \mathrm{x} \mathrm{d}, \mathrm{J}=19.0 \mathrm{~Hz}, \mathrm{H}-1^{\prime}\right), 2.42(2 \mathrm{H}, \mathrm{m})$ 2.30-2.50 (1 H, m), 2.12 (3 $\left.\mathrm{H}, \mathrm{s}, \mathrm{COCH}_{3}\right), 1.50-1.70(3 \mathrm{H}, \mathrm{m}), 1.71\left(3 \mathrm{H}\right.$, s, olefinic $\left.\mathrm{CH}_{3}\right), 1.00\left(3 \mathrm{H}\right.$, s, tert- $\left.\mathrm{CH}_{3}\right), 0.89(3 \mathrm{H}$, $\mathrm{d}, \mathrm{J}=6.4 \mathrm{~Hz}$, sec $\left.-\mathrm{CH}_{3}\right) .{ }^{13} \mathrm{C} \mathrm{NMR}\left(50 \mathrm{MHz}, \mathrm{CHCl}_{3}+\mathrm{CDCl}_{3}\right): \delta 214.2(\mathrm{C}-1), 207.1\left(\mathrm{CH}_{3} \mathrm{C}=\mathrm{O}\right)$, $147.4\left(\mathrm{C}=\mathrm{CH}_{2}\right), 109.3\left(\mathrm{C}=\mathrm{CH}_{2}\right), 50.6(\mathrm{C}-2), 48.0\left(\mathrm{CH}_{2} \mathrm{COCH}_{3}\right), 42.9,42.7,36.4,35.0,30.8$ $\left(\mathrm{COCH}_{3}\right), 20.3$, 18.5, 15.7. Mass: m/z $222\left(\mathrm{M}^{+}, 2 \%\right), 165$ (100), 149 (10). HRMS: m/z for $\mathrm{C}_{13} \mathrm{H}_{19} \mathrm{O}_{2}$ (M -Me), Calcd.: 207.1385. Found: 207.1390. For the minor diketone 17b: IR (neat): $v_{\max } 3060,1700,1660,890 \mathrm{~cm}^{-1} .{ }^{1} \mathrm{H}$ NMR $\left(90 \mathrm{MHz}, \mathrm{CDCl}_{3}\right): \delta 4.75\left(2 \mathrm{H}, \mathrm{br} \mathrm{s}, \mathrm{C}=\mathrm{CH}_{2}\right), 2.90$ and $2.60\left(2 \mathrm{H}, 2 \mathrm{x} \mathrm{d}, \mathrm{J}=18 \mathrm{~Hz}, \mathrm{CH}_{2} \mathrm{COCH}_{3}\right), 2.30-2.50(3 \mathrm{H}, \mathrm{m}), 2.10\left(3 \mathrm{H}, \mathrm{s}, \mathrm{COCH}_{3}\right), 1.70(3$ $\mathrm{H}$, s, olefinic $\left.\mathrm{CH}_{3}\right), 1.40-1.70(3 \mathrm{H}, \mathrm{m}), 1.06\left(3 \mathrm{H}, \mathrm{s}\right.$, tert $\left.-\mathrm{CH}_{3}\right), 0.97\left(3 \mathrm{H}, \mathrm{d}, \mathrm{J}=6.0 \mathrm{~Hz}, \mathrm{sec}-\mathrm{CH}_{3}\right)$. ${ }^{13} \mathrm{C}$ NMR $\left(22.5 \mathrm{MHz}, \mathrm{CDCl}_{3}\right): \delta 210.9(\mathrm{C}-1), 205.6\left(\mathrm{CH}_{3} \mathrm{C}=\mathrm{O}\right), 146.4\left(\mathrm{C}=\mathrm{CH}_{2}\right), 108.4\left(\mathrm{C}=\mathrm{CH}_{2}\right)$, 48.7 (C-2), 45.4, 44.7, 42.5, 41.9, 33.9, $30.0\left(\mathrm{COCH}_{3}\right), 19.4,18.8,14.8 . \mathrm{Mass}: \mathrm{m} / \mathrm{z} 222\left(\mathrm{M}^{+}\right.$, 16\%), 204 (10), 179 (12), 165 (100), 149 (16), 137 (20), 121 (23), 109 (42), 95 (58). Anal. for $\mathrm{C}_{14} \mathrm{H}_{22} \mathrm{O}_{2}$, Calcd.: C, 75.63, H, 9.97. Found: C, 75.30, H, 9.96\%.

(-)-(1R,2S,4R)-4-Isopropenyl-1,2-dimethylbicyclo[4.3.0]non-6-en-8-one (18). To a solution of the diketone 17a (473 $\mathrm{mg}, 2.13 \mathrm{mmol})$ in $1 \mathrm{ml}$ of methanol was added $10 \% \mathrm{aq}$. KOH $(1.43 \mathrm{~mL}$, $2.56 \mathrm{mmol}$ ), and the reaction mixture was heated in a sealed tube at $110{ }^{\circ} \mathrm{C}$ for $3.5 \mathrm{~h}$. It was cooled and extracted with ether $(3 \times 10 \mathrm{ml})$. The ether extract was washed with water followed by brine and dried $\left(\mathrm{Na}_{2} \mathrm{SO}_{4}\right)$. Evaporation of the solvent and purification of the residue over a silica gel column using ethyl acetate-hexane (1:10) as eluent, furnished the enone 18 (364 mg, $84 \%$ ) as yellow oil. $[\alpha]_{\mathrm{D}}{ }^{28}:-103\left(\mathrm{c} 1.3, \mathrm{CHCl}_{3}\right)$. IR (neat): $v_{\max } 1705,1620,890 \mathrm{~cm}^{-1} .{ }^{1} \mathrm{H} \mathrm{NMR}$ $\left(270 \mathrm{MHz}, \mathrm{CDCl}_{3}\right): \delta 5.79(1 \mathrm{H}, \mathrm{s}, \mathrm{H}-7), 4.78\left(2 \mathrm{H}, \mathrm{s}, \mathrm{C}=\mathrm{CH}_{2}\right), 2.68(1 \mathrm{H}, \mathrm{d}, \mathrm{J}=11.2 \mathrm{~Hz}, \mathrm{H}-9 \mathrm{a})$, 2.10-2.40 (4 H, m), $1.77\left(3 \mathrm{H}, \mathrm{s}\right.$, olefinic $\left.\mathrm{CH}_{3}\right), 1.20-1.70(3 \mathrm{H}, \mathrm{m}), 1.10\left(3 \mathrm{H}, \mathrm{s}\right.$, tert $\left.-\mathrm{CH}_{3}\right), 0.97$ $\left(3 \mathrm{H}, \mathrm{d}, \mathrm{J}=6.5 \mathrm{~Hz}\right.$, sec-CH $\left.\mathrm{CH}_{3}\right){ }^{13} \mathrm{C} \mathrm{NMR}\left(22.5 \mathrm{MHz}, \mathrm{CDCl}_{3}\right): \delta 205.3(\mathrm{~s}, \mathrm{C}=\mathrm{O}), 186.2(\mathrm{~s}, \mathrm{C}-6)$, $146.8\left(\mathrm{~s}, \mathrm{C}=\mathrm{CH}_{2}\right), 125.2$ (d, C-7), $108.5\left(\mathrm{t}, \mathrm{C}=\mathrm{CH}_{2}\right), 49.1$ (t, C-9), 45.3 (d, C-4), 44.9 (s, C-1), 41.2 (d, C-2), 34.0 (t), 31.1 (t), 19.5 (q), 17.2 (q), 15.9 (q). 2,4-DNP derivative, m.p. 158-159 ${ }^{\circ} \mathrm{C}$. Anal. for $\mathrm{C}_{20} \mathrm{H}_{24} \mathrm{~N}_{4} \mathrm{O}_{4}$, Calcd.: C, 62.49; H, 6.29; N, 14.57. Found: C, 62.47; H, 6.42; N, 14.24\%. (-)-(1R,2S,4R,6R)-4-Isopropenyl-1,2-dimethylbicyclo[4.3.0]nonan-8-one (15). To a dark blue 
colored solution of lithium $(80 \mathrm{mg}, 11.5 \mathrm{mmol})$ in $180 \mathrm{ml}$ of freshly distilled ammonia was added, drop wise, a solution of the enone $18(540 \mathrm{mg}, 2.64 \mathrm{mmol})$ and $t$-BuOH $(0.5 \mathrm{~mL}$, $5.33 \mathrm{mmol}$ ) in $20 \mathrm{ml}$ of dry THF over a period of $15 \mathrm{~min}$. The reaction mixture was stirred for 2 $\mathrm{h}$ and then quenched with ammonium chloride. Ammonia was evaporated; reaction mixture was diluted with water and extracted with ether $(3 \times 25 \mathrm{~mL})$. The ether extract was washed with brine and dried $\left(\mathrm{Na}_{2} \mathrm{SO}_{4}\right)$. Evaporation of the solvent furnished a mixture of hydrindanone $\mathbf{1 5}$ and the corresponding alcohol. To the crude mixture of ketone and alcohol in $\mathrm{CH}_{2} \mathrm{Cl}_{2}(5 \mathrm{ml})$ was added PCC (1 g, $4.65 \mathrm{mmol})$ and silica gel $(1 \mathrm{~g})$, stirred for $2 \mathrm{~h}$ and filtered through a small silica gel column. Evaporation of the solvent and purification of the residue over a silica gel column using ethyl acetate-hexane (1:40 to 1:20) as eluent furnished the ketone 15 (456 $\mathrm{mg}, 84 \%)$ as an oil. $[\alpha]_{\mathrm{D}}^{28}$ : -66 (c 1.3, $\left.\mathrm{CHCl}_{3}\right)$. IR (neat): $v_{\max } 3075,1745,1645,885 \mathrm{~cm}^{-1}$. ${ }^{1} \mathrm{H}$ NMR $(270 \mathrm{MHz}$, $\left.\mathrm{CDCl}_{3}\right): \delta 4.72\left(2 \mathrm{H}\right.$, br s, $\left.\mathrm{C}=\mathrm{CH}_{2}\right), 2.42$ and $1.98(2 \mathrm{H}, 2 \mathrm{x} \mathrm{d}, \mathrm{J}=18 \mathrm{~Hz}, \mathrm{H}-9), 2.10-2.40$ (3 H, m), $1.73\left(3 \mathrm{H}, \mathrm{s}\right.$, olefinic $\left.\mathrm{CH}_{3}\right), 1.10-1.70(3 \mathrm{H}, \mathrm{m}), 1.05\left(3 \mathrm{H}, \mathrm{s}\right.$, tert $\left.-\mathrm{CH}_{3}\right), 0.84(3 \mathrm{H}, \mathrm{d}, \mathrm{J}=6.3 \mathrm{~Hz}$, sec- $\left.\mathrm{CH}_{3}\right) .{ }^{13} \mathrm{C}$ NMR $\left(100 \mathrm{MHz}, \mathrm{CDCl}_{3}\right): \delta 218.6(\mathrm{C}=\mathrm{O}), 149.6\left(\mathrm{C}=\mathrm{CH}_{2}\right), 108.8\left(\mathrm{C}=\mathrm{CH}_{2}\right), 53.1$, 43.9, 40.9, 40.7, 39.1, 35.4, 35.8, 28.6, 21.0, 19.0, 16.4. Mass: m/z $206\left(\mathrm{M}^{+}, 30 \%\right), 191$ (10), 163 (30), 149 (25), 135 (15), 121 (40), 109 (100). HRMS: m/z for $\mathrm{C}_{14} \mathrm{H}_{22} \mathrm{O}$, Calcd.: 206.1671. Found: 206.1679 .

(-)-(1R,2S,6R)-4-Isopropylidene-1,2-dimethylbicyclo[4.3.0]nonan-8-one (20). To an ice cold magnetically stirred saturated solution of $\mathrm{HBr}$ in dry ether $(50 \mathrm{ml})$ was added hydrindanone 15 (368 mg, $1.79 \mathrm{mmol}$ ) in $2 \mathrm{ml}$ of dry ether. The reaction mixture was stirred at the same temp for $6 \mathrm{~h}$, diluted with ether $(30 \mathrm{ml})$, washed sequentially with water, aq. $\mathrm{NaHCO}_{3}$ and brine, and dried $\left(\mathrm{Na}_{2} \mathrm{SO}_{4}\right)$. Evaporation of the solvent furnished the tertiary bromide 19, which was taken in $5 \mathrm{ml}$ of benzene and DBU $(0.323 \mathrm{~mL}, 2.12 \mathrm{mmol})$ was added and heated in a sealed tube at $130{ }^{\circ} \mathrm{C}$ for $30 \mathrm{~min}$. The reaction mixture was then cooled, diluted with water and extracted with ether $(3 \mathrm{x}$ $10 \mathrm{ml}$ ). The ether extract was washed with $3 \mathrm{~N} \mathrm{HCl}$, saturated $\mathrm{NaHCO}_{3}$ solution and brine, and dried $\left(\mathrm{Na}_{2} \mathrm{SO}_{4}\right)$. Evaporation of the solvent and purification of the residue over a silica gel column using ethyl acetate-hexane (1:20) as eluent furnished the isopropylidene compound 20 containing a trace amount of the starting material $15\left(328 \mathrm{mg}, 89 \%\right.$ in two steps). $[\alpha]_{\mathrm{D}}{ }^{26}:-79$ (c 2.7, $\mathrm{CHCl}_{3}$ ). IR (neat): $v_{\max } 1740 \mathrm{~cm}^{-1} .{ }^{1} \mathrm{H} \mathrm{NMR}\left(90 \mathrm{MHz}, \mathrm{CDCl}_{3}\right): \delta 2.35(1 \mathrm{H}, \mathrm{d}, \mathrm{J}=18 \mathrm{~Hz})$, $2.16(2 \mathrm{H}, \mathrm{s}), 1.93(1 \mathrm{H}, \mathrm{d}, \mathrm{J}=18 \mathrm{~Hz}), 1.60-2.60$ (6 H, m), $1.68(3 \mathrm{H}, \mathrm{s}), 1.63(3 \mathrm{H}, \mathrm{s}), 1.10$ (3 H, $\mathrm{s}$, tert- $\left.\mathrm{CH}_{3}\right), 0.85\left(3 \mathrm{H}, \mathrm{d}, \mathrm{J}=6.3 \mathrm{~Hz}\right.$, sec- $\left.\mathrm{CH}_{3}\right) .{ }^{13} \mathrm{C} \mathrm{NMR}\left(22.5 \mathrm{MHz}, \mathrm{CDCl}_{3}\right): \delta 218.7(\mathrm{~s}, \mathrm{C}=\mathrm{O})$, $127.1(\mathrm{~s}), 123.9(\mathrm{~s}), 52.4(\mathrm{t}), 45.0(\mathrm{~d}), 40.8(\mathrm{~s}), 40.4(\mathrm{t}), 35.3(\mathrm{~d}), 33.8(\mathrm{t}), 28.3(\mathrm{t}), 19.7(2 \mathrm{C}, \mathrm{q})$, 18.7 (q), 16.1 (q). Mass: m/z 206 (M+, 80\%), 163 (40), 149 (45), 121 (75), 110 (40), 109 (100), 107 (50). HRMS: $\mathrm{m} / \mathrm{z}$ for $\mathrm{C}_{14} \mathrm{H}_{22} \mathrm{O}$, Calcd.: 206.1671. Found: 206.1668.

(-)-(1R,5S,6R)-5,6-Dimethylbicyclo[4.3.0]nonan-3,8-dione (21). Through a cold $\left(-90{ }^{\circ} \mathrm{C}\right)$ solution of the compound 20 (390 $\mathrm{mg}, 1.89 \mathrm{mmol})$, methanol $(0.4 \mathrm{ml})$ and $\mathrm{NaHCO}_{3}$ (catalytic) in $10 \mathrm{ml}$ of $\mathrm{CH}_{2} \mathrm{Cl}_{2}$ was passed a stream of pre-cooled ozone in oxygen gas until the reaction mixture turned to blue in color. Excess ozone was flushed off by passing oxygen gas. Triphenylphosphine (500 $\mathrm{mg}, 1.9 \mathrm{mmol}$ ) was added to the reaction mixture, allowed it to warm up to RT and stirred for $8 \mathrm{~h}$. Evaporation of the solvent and purification of the residue over a silica gel column using ethyl acetate-hexane (1:5 to 2:5) as eluent furnished the dione 21 (300 mg, 88\%). [ $\alpha \mathrm{D}^{24}:-114$ (c 2.1, $\mathrm{CHCl}_{3}$ ). IR (neat): $v_{\max } 1740,1710 \mathrm{~cm}^{-1}$. ${ }^{1} \mathrm{H}$ NMR $(200$ $\left.\mathrm{MHz}, \mathrm{CDCl}_{3}\right): \delta$ 1.70-2.80 $(10 \mathrm{H}, \mathrm{m}), 1.21\left(3 \mathrm{H}, \mathrm{s}\right.$, tert $\left.-\mathrm{CH}_{3}\right), 0.90\left(3 \mathrm{H}, \mathrm{d}, \mathrm{J}=6.6 \mathrm{~Hz}, \mathrm{sec}-\mathrm{CH}_{3}\right)$. 
${ }^{13} \mathrm{C}$ NMR (100 MHz, $\left.\mathrm{CDCl}_{3}\right): \delta 215.9(\mathrm{C}, \mathrm{C}-8), 210.4(\mathrm{C}, \mathrm{C}-3), 51.9\left(\mathrm{CH}_{2}\right), 45.5(\mathrm{CH}), 45.0$ $\left(\mathrm{CH}_{2}\right), 42.0\left(\mathrm{CH}_{2}\right), 40.7\left(2 \mathrm{C}, \mathrm{C} \& \mathrm{CH}_{2}\right), 35.7(\mathrm{CH}), 18.7\left(\mathrm{CH}_{3}\right.$, tert- $\left.\mathrm{CH}_{3}\right), 16.6\left(\mathrm{CH}_{3}\right.$, sec $\left.-\mathrm{CH}_{3}\right)$. Mass: m/z $180\left(\mathrm{M}^{+}, 25 \%\right), 111$ (10), 95 (10), 69 (100). HRMS: m/z for $\mathrm{C}_{11} \mathrm{H}_{16} \mathrm{O}_{2}$, Calcd.: 180.1150. Found: 180.1143 .

(-)-(1R,2S,6S)-4,4-Ethylenedioxy-1,2-dimethylbicyclo[4.3.0]nonan-8-one (13). A magnetically stirred solution of the dione $21(320 \mathrm{mg}, 1.77 \mathrm{mmol})$, ethylene glycol $(0.1 \mathrm{ml}, 1.8 \mathrm{mmol})$ and a catalytic amount of p-TSA in $50 \mathrm{ml}$ of dry benzene was refluxed using a Dean-Stark water separator for $3 \mathrm{~h}$. It was cooled, washed with saturated aqueous $\mathrm{NaHCO}_{3}$ solution and dried $\left(\mathrm{Na}_{2} \mathrm{SO}_{4}\right)$. Evaporation of the solvent under reduced pressure and purification of the product over a silica gel column using ethyl acetate-hexane (1:5) as eluent furnished the ketoketal $13(260 \mathrm{mg}, 65 \%)$ as oil. $[\alpha]_{\mathrm{D}}{ }^{25}$ : -64 (c 2.1, $\left.\mathrm{CHCl}_{3}\right)\left\{\right.$ For the $(1 S, 2 R, 6 R)$-enantiomer $[\alpha]_{\mathrm{D}}^{25}:+69$ (c 1.64, $\left.\left.\mathrm{CHCl}_{3}\right)\right\}$. IR (neat): $v_{\max } 1730 \mathrm{~cm}^{-1}$. ${ }^{1} \mathrm{H}$ NMR $\left(270 \mathrm{MHz}, \mathrm{CDCl}_{3}\right): \delta 3.85-4.00\left(4 \mathrm{H}, \mathrm{m}, \mathrm{OCH}_{2} \mathrm{CH}_{2} \mathrm{O}\right), 2.93(1 \mathrm{H}, \mathrm{d}$ of $\mathrm{t}, \mathrm{J}=16.0$ and 7.0 $\mathrm{Hz}), 1.40-2.50(9 \mathrm{H}, \mathrm{m}), 1.06\left(3 \mathrm{H}, \mathrm{s}\right.$, tert $\left.-\mathrm{CH}_{3}\right), 0.85\left(3 \mathrm{H}, \mathrm{d}, \mathrm{J}=6.7 \mathrm{~Hz}\right.$, sec $\left.-\mathrm{CH}_{3}\right) .{ }^{13} \mathrm{C} \mathrm{NMR}(50$ $\left.\mathrm{MHz}, \mathrm{CHCl}_{3}+\mathrm{CDCl}_{3}\right): \delta 219(\mathrm{C}=\mathrm{O}), 109(\mathrm{O}-\mathrm{C}-\mathrm{O}), 64.4$ and $63.5\left(\mathrm{OCH}_{2} \mathrm{CH}_{2} \mathrm{O}\right), 58.3,52.2,43.5$, 41.5, 38.5, 31.8, 31.4, 18.4, 16.0. Mass: m/z 224 (M+, 5\%), 154 (35), 139 (10), 113 (100). HRMS: $\mathrm{m} / \mathrm{z}$ for $\mathrm{C}_{13} \mathrm{H}_{20} \mathrm{O}_{3}$, Calcd.: 224.1412. Found: 224.1416.

$(1 S, 5 S, 6 R, 8 R)$ and (1S,5S,6R,8S)-5,6-Dimethylbicyclo[4.3.0]nonan-3-one-8,3'-spiro[4'methylenedihydrofuran-2'(3'H)-one] (12) and (26). To a magnetically stirred solution of potassium tertiary amyloxide $(292 \mathrm{mg}, 2.32 \mathrm{mmol})$ in dry THF (3 mL) at RT was added methoxymethyltriphenyphosphonium chloride $(944 \mathrm{mg}, 2.76 \mathrm{mmol})$ and the resulting red colored solution was stirred at RT for $15 \mathrm{~min}$. To the methoxymethylenetriphenylphosphorane thus formed, was added the ketoketal $13(165 \mathrm{mg}, 0.736 \mathrm{mmol})$ and stirred at RT for $6 \mathrm{~h}$. The reaction mixture was then diluted with ether $(10 \mathrm{ml})$, washed with brine and dried $\left(\mathrm{Na}_{2} \mathrm{SO}_{4}\right)$. Evaporation of the solvent and purification of the residue over a neutral alumina column using ethyl acetate-hexane (1:40 to 1:20) as eluent furnished a E,Z mixture of the enol ether 22 as a colourless oil, which was contaminated with small amount of triphenylphosphine. IR (neat): $v_{\max }$ $1685 \mathrm{~cm}^{-1} .{ }^{1} \mathrm{H}$ NMR $\left(90 \mathrm{MHz}, \mathrm{CDCl}_{3}\right): \delta 5.83(1 \mathrm{H}$, br s, olefinic $\mathrm{H}), 3.90(4 \mathrm{H}$, br s, $\left.\mathrm{OCH}_{2} \mathrm{CH}_{2} \mathrm{O}\right), 3.52\left(3 \mathrm{H}, \mathrm{s}, \mathrm{OCH}_{3}\right), 1.20-2.80(10 \mathrm{H}, \mathrm{m}), 0.93$ and $0.90\left(3 \mathrm{H}, \mathrm{s}\right.$, tert- $\left.\mathrm{CH}_{3}\right), 0.84$ and $0.81\left(3 \mathrm{H}, \mathrm{d}, \mathrm{J}=6.3 \mathrm{~Hz}\right.$, sec- $\left.\mathrm{CH}_{3}\right)$. To a cold $\left(-40{ }^{\circ} \mathrm{C}\right)$, magnetically stirred solution of NBS (200 mg, $1.12 \mathrm{mmol}$ ) and propargyl alcohol $(385 \mathrm{mg}, 0.4 \mathrm{ml}, 6.87 \mathrm{mmol})$ in $\mathrm{CH}_{2} \mathrm{Cl}_{2}$ (4 ml) was added a solution of the enol ether 22 in $\mathrm{CH}_{2} \mathrm{Cl}_{2}(2 \mathrm{ml})$ over a period of $10 \mathrm{~min}$. The reaction mixture was stirred for $45 \mathrm{~min}$ at the same temperature, diluted with $\mathrm{CH}_{2} \mathrm{Cl}_{2}(5 \mathrm{ml})$, washed with $1 \%$ aq. $\mathrm{NaOH}$ solution $(5 \mathrm{ml})$ followed by brine, and dried $\left(\mathrm{Na}_{2} \mathrm{SO}_{4}\right)$. Evaporation of the solvent and purification of the residue on a neutral alumina column using ethyl acetate-hexane (1:20 to 1:10) as eluent furnished a diastereomeric mixture of the bromoacetal $23(160 \mathrm{mg}, 56 \%$ overall yield from ketoketal 13) as a colourless oil. IR (neat): $v_{\max } 3280,2120 \mathrm{~cm}^{-1}$. ${ }^{1} \mathrm{H}$ NMR $(90 \mathrm{MHz}$, $\mathrm{CDCl}_{3}$, mixture of diastereomers): $\delta 4.60 \& 4.54(1 \mathrm{H}, \mathrm{s}, \mathrm{O}-\mathrm{CH}-\mathrm{O}), 4.45(2 \mathrm{H}, \mathrm{d}, \mathrm{J}=2.5 \mathrm{~Hz}$, $\left.\mathrm{OCH}_{2} \mathrm{C} \equiv \mathrm{CH}\right), 3.90\left(4 \mathrm{H}\right.$, br s, $\left.\mathrm{OCH}_{2} \mathrm{CH}_{2} \mathrm{O}\right), 3.65 \& 3.64\left(3 \mathrm{H}, \mathrm{s}, \mathrm{OCH}_{3}\right), 2.50(1 \mathrm{H}, \mathrm{t}, \mathrm{J}=2.5 \mathrm{~Hz}$, $\mathrm{C} \equiv \mathrm{CH}), 1.20-2.70(10 \mathrm{H}, \mathrm{m}), 1.04\left(3 \mathrm{H}, \mathrm{s}\right.$, tert- $\left.\mathrm{CH}_{3}\right), 0.88(\mathrm{~d}, \mathrm{~J}=5.8 \mathrm{~Hz}) \& 0.78(\mathrm{~d}, \mathrm{~J}=6.8 \mathrm{~Hz})[3$ $\mathrm{H}$, sec $-\mathrm{CH}_{3}$ ]. A magnetically stirred solution of the bromoacetal 23 (159 mg, $0.4 \mathrm{mmol}$ ), tri-nbutyltin chloride $(0.02 \mathrm{~mL}, 0.075 \mathrm{mmol}), \mathrm{NaCNBH}_{3}(70 \mathrm{mg}, 1.12 \mathrm{mmol})$ and a catalytic amount of AIBN in $t$-BuOH $(2.5 \mathrm{ml})$ was refluxed for $2 \mathrm{~h}$. The solvent was then evaporated under reduced pressure. The residue was taken in water $(3 \mathrm{~mL})$ and extracted with ether $(3 \mathrm{x} 5 \mathrm{~mL})$. 
The ether extract was washed with $1 \%$ aq. ammonia solution followed by brine, and dried $\left(\mathrm{Na}_{2} \mathrm{SO}_{4}\right)$. Evaporation of the solvent and purification of the residue over a silica gel column using ethyl acetate-hexane (1:40) as eluent furnished an epimeric mixture of the spiroacetal 24 (102 mg, 82\%) as a colourless oil. IR (neat): $v_{\max } 3080,1660,875 \mathrm{~cm}^{-1}$. ${ }^{1} \mathrm{H}$ NMR (90 MHz, $\left.\mathrm{CDCl}_{3}\right): \delta$ 4.80-5.00 (2 H, m, C= $\left.=\mathrm{CH}_{2}\right), 4.66 \& 4.58(1 \mathrm{H}, \mathrm{s}, \mathrm{CHOMe}), 4.30-4.50(2 \mathrm{H}, \mathrm{m}$, $\left.\mathrm{OCH}_{2} \mathrm{C}=\right), 3.85-4.00\left(4 \mathrm{H}, \mathrm{m}, \mathrm{OCH}_{2} \mathrm{CH}_{2} \mathrm{O}\right), 3.34\left(3 \mathrm{H}, \mathrm{s}, \mathrm{OCH}_{3}\right), 1.20-2.70(10 \mathrm{H}, \mathrm{m}), 1.13$ \& $0.91\left(3 \mathrm{H}, \mathrm{s}\right.$, tert $\left.-\mathrm{CH}_{3}\right), 0.74-0.90\left(3 \mathrm{H}, \mathrm{m}\right.$, sec $\left.-\mathrm{CH}_{3}\right)$. A solution of the spiroacetal $24(50 \mathrm{mg}$, $0.162 \mathrm{mmol})$ in THF $(1 \mathrm{ml})$ and $3 \mathrm{~N} \mathrm{HCl}(2 \mathrm{ml})$ was stirred for $4 \mathrm{~h}$ at RT. The reaction mixture was diluted with ether $(5 \mathrm{ml})$, washed with water, saturated aq. $\mathrm{NaHCO}_{3}$ solution and brine, and dried $\left(\mathrm{Na}_{2} \mathrm{SO}_{4}\right)$. The solvent was evaporated and the residue was filtered through a silica gel column using ethyl acetate-hexane (1:5 to 2:5) as eluent to furnish an epimeric mixture of the ketospirolactol $25(22.5 \mathrm{mg}, 56 \%)$. IR (neat): $v_{\max } 3400,1710,880 \mathrm{~cm}^{-1}$. To a magnetically stirred solution of the spirolactol $25(22.5 \mathrm{mg}, 0.09 \mathrm{mmol})$ in $\mathrm{CH}_{2} \mathrm{Cl}_{2}(0.3 \mathrm{ml})$ was added a homogeneous mixture of PCC (25 mg, $0.12 \mathrm{mmol})$ and silica gel $(25 \mathrm{mg})$. The reaction mixture was stirred at RT for $4 \mathrm{~h}$ and then filtered through a silica gel column using $\mathrm{CH}_{2} \mathrm{Cl}_{2}$ as eluent. Evaporation of the solvent and careful purification of the residue on a silica gel column using ethyl acetate-hexane (1:5 to 2:5) as eluent furnished the ketospirolactones 12 (4 mg, 18\%) and 26 (14 mg, 63\%). For the ketospirolactone 12: $[\alpha]_{\mathrm{D}}{ }^{26}:-45\left(\mathrm{c} 1.0, \mathrm{CHCl}_{3}\right) .{ }^{1} \mathrm{H} \mathrm{NMR}(270 \mathrm{MHz}$, $\left.\mathrm{CDCl}_{3}\right): \delta 5.06\left(2 \mathrm{H}\right.$, br s, $\left.\mathrm{C}=\mathrm{CH}_{2}\right), 4.76\left(2 \mathrm{H}\right.$, br s, $\left.\mathrm{OCH}_{2}\right), 2.55-2.75(2 \mathrm{H}, \mathrm{m}), 2.00-2.35(5 \mathrm{H}$, $\mathrm{m}), 2.02$ and $2.12\left(2 \mathrm{H}, \mathrm{AB}\right.$ q, J=14.4 Hz), $1.73(1 \mathrm{H}, \mathrm{t}, \mathrm{J}=13.3 \mathrm{~Hz}), 1.22\left(3 \mathrm{H}, \mathrm{s}\right.$, tert- $\left.\mathrm{CH}_{3}\right), 1.00$ $\left(3 \mathrm{H}, \mathrm{d}, \mathrm{J}=6.5 \mathrm{~Hz}\right.$, sec- $\left.\mathrm{CH}_{3}\right)$. For the epi ketospirolactone (26): $[\alpha] \mathrm{D}^{24}:+35.0\left(\mathrm{c} 1.0, \mathrm{CHCl}_{3}\right)$. $\left\{\right.$ For the $(1 R, 5 R, 6 S, 8 R)$-enantiomer $\left.[\alpha]_{\mathrm{D}}{ }^{26}:-33\left(\mathrm{c} 1.5, \mathrm{CHCl}_{3}\right)\right\}$. IR (neat): $v_{\max } 3080,1760,1700$, $1665,890 \mathrm{~cm}^{-1} .{ }^{1} \mathrm{H}$ NMR $\left(270 \mathrm{MHz}, \mathrm{CDCl}_{3}\right): \delta 5.11(1 \mathrm{H}, \mathrm{s})$ and $5.05(1 \mathrm{H}, \mathrm{s})\left[\mathrm{C}=\mathrm{CH}_{2}\right], 4.79(2$ $\mathrm{H}$, br s, $\left.\mathrm{OCH}_{2}\right), 2.00-2.60(8 \mathrm{H}, \mathrm{m}), 1.89(1 \mathrm{H}, \mathrm{dd}, \mathrm{J}=12.8$ and $6.6 \mathrm{~Hz}), 1.68(1 \mathrm{H}, \mathrm{d}, \mathrm{J}=14 \mathrm{~Hz})$, $1.19\left(3 \mathrm{H}, \mathrm{s}\right.$, tert- $\left.\mathrm{CH}_{3}\right), 0.96\left(3 \mathrm{H}, \mathrm{d}, \mathrm{J}=6.6 \mathrm{~Hz}\right.$, sec $\left.-\mathrm{CH}_{3}\right) .{ }^{13} \mathrm{C} \mathrm{NMR}\left(50 \mathrm{MHz}, \mathrm{CDCl}_{3}\right): \delta 210.6$ $(\mathrm{C}=\mathrm{O}), 181.1(\mathrm{OC}=\mathrm{O}), 151.1\left(\mathrm{C}=\mathrm{CH}_{2}\right), 106.0\left(\mathrm{C}=\mathrm{CH}_{2}\right), 70.1\left(\mathrm{OCH}_{2}\right), 49.8$ (spiro $\left.C\right), 49.3,49.1$, 45.1, 44.0, 43.4, 40.4, 34.4, 19.2, 16.4. Mass: m/z $248\left(\mathrm{M}^{+}, 18 \%\right), 164$ (76), 138 (18), 119 (28), 105 (20), 84 (100), 69 (75). HRMS: m/z for $\mathrm{C}_{15} \mathrm{H}_{20} \mathrm{O}_{3}$, Calcd.: 248.1412. Found: 248.1424.

\section{Acknowledgements}

We thank Professor A. E. Greene for providing the spectral data for the spirolactone 12, the Department of Science and Technology for the financial support and the University Grants Commission for the award of a fellowship to TJR.

\section{References}

1. (a) Fraga, B. M. Nat. Prod. Rep. 1985, 2, 147; 1986, 3, 273; 1987, 4, 473; 1988, 5, 497; 1990, 7, 61 and 515; 1992, 9, 217 and 557; 1993, 10, 397; 1994, 11, 533; 1995, 12, 303; 1996, 13, 307; 1997, 14, 145; 1998, 15, 73; 1999, 16, 21 and 711; 2000, 17, 483. (b) Gribble, G. W. In 'Progress in the Chemistry of Organic Natural Products' Herz, W.; Kirby, G. W.; Moore, R. E.; Steglich, W.; Tamm, Ch., Eds; Springer Wien: New York, 1996; Vol. 68, pp 1-87. (c) Asakawa, Y. In Progress in the Chemistry of Organic Natural 
Products' Herz, W.; Kirby, G. W.; Moore, R. E.; Steglich, W.; Tamm, Ch., Eds; Springer Wien New York, 1995; Vol 65, pp 1-296. (d) Christensen, S. B.; Andersen, A.; Smitt, U. W. in Progress in the Chemistry of Organic Natural Products' Herz, W.; Kirby, G. W.; Moore, R. E.; Steglich, W.; Tamm, Ch., Eds; Springer Wien: New York, 1997; Vol 71,pp 129-167.

2. (a) Heathcock, C. H. In 'The Total Synthesis of Natural Products', ApSimon, Ed.; J. Wiley: New York, 1973; Vol. 2, pp. 197-558. (b) Heathcock, C. H.; Graham, S. L.; Pirrung, M. C.; Plavac, F.; White, C. T. in 'The Total Synthesis of Natural Products' ApSimon, J. Ed.; Wiley: New York, 1983; Vol. 5.

3. Harmatha, J.; Samek, Z.; Synackova, M.; Novotny, L.; Herout, V.; Sorm, F. Collect. Czech. Chem. Commun., 1976, 41, 2047.

4. Fischer, N. H.; Olivier, E. J.; Fischer, H. D. in 'Progress in the Chemistry of Organic Natural Products' Herz, W.; Grisebach, H.; Kirby, G. W., Eds; Springer-Verlag: New York, 1979; Vol 38, Ch 2, and references cited therin.

5. (a) Jamieson, G. R.; Reid, E. H.; Turner, B. P.; Jamieson, A. T. Phytochemistry 1976, 15, 1713. (b) Kano, K.; Hayashi, K.; Mitsuhashi, H. Chem. Pharm. Bull. 1982, 30, 1198.

6. Bakkenolides and Palmosolide-C: (a) Evans, D. A.; Sims, C. L. Tetrahedron Lett. 1973, 4691. (b) Evans, D. A.; Sims, C. L.; Andrews, G. C. J. Am. Chem. Soc. 1977, 99, 5453. (c) Greene, A. E.; Depres, J.-P.; Coelho, F.; Brocksom, T. J. J. Org. Chem., 1985, 50, 3943. (d) Greene, A. E.; Coelho, F.; Depres, J.-P.; Brocksom, T. J. Tetrahedron Lett. 1988, 29, 5661. (e) Hayashi, K.; Nakamura, H.; Mitsuhashi, H. Chem. Pharm. Bull. 1973, 21, 2806. (f) Hartman, B.; Depres, J.-P.; Greene, A. E.; Freire de Lima, M. E. Tetrahedron Lett. 1993, 34, 1487. (g) Srikrishna, A.; Reddy, T. J.; Nagaraju, S.; Sattigeri, J. A. Tetrahedron Lett. 1994, 35, 7841. (h) Srikrishna, A.; Reddy, T. J. Tetrahedron 1998, 54, 11517. (i) Srikrishna, A.; Viswajanani, R.; Sattigeri, J. A. J. Chem. Soc., Chem. Commun., 1995, 469. (j) Hamelin, O.; Depres, J.-P.; Greene, A. E.; Tinant, B.; Declercq, J.-P. J. Am. Chem. Soc. 1996, 118, 9992. (k) Back, T. G.; Payne, J. E. Org. Lett, 1999, 1, 663.

7. Homogynolide-A: (a) B. Hartmann, A. M. Kanazawa, J.-P. Depres and A. E. Greene, Tetrahedron Lett. 1991, 32, 767. (b) Hartmann, B.; Kanazawa, A. M.; Depres, J.-P.; Greene, A. E. Tetrahedron Lett. 1993, 34, 3875. (c) K. Mori and Y. Matsushima Synthesis 1995, 845 .

8. Homogynolide-B: (a) Coelho, F.; Depres, J.-P.; Brocksom, T. J.; Greene, A. E. Tetrahedron Lett., 1989, 30, 565. (b) Srikrishna, A.; Nagaraju, S.; Venkateswarlu, S. Tetrahedron Lett. 1994, 35, 429. (c) Srikrishna, A.; Nagaraju, S.; Venkateswarlu, S., Hiremath, U. S.; Reddy, T. J.; Venugopalan, P. J. Chem. Soc., Perkin Trans. 1 1999, 2069.

9. For a preliminary communication, see: Srikrishna, A.; Reddy, T. J. Indian J. Chem., Sec. B 1995, 34B, 844.

10. Srikrishna, A.; Nagaraju, S.; Sharma, G. V. R. J. Chem. Soc., Chem. Commun. 1993, 285.

11. Srikrishna, A.; Hemamalini, P. Indian J. Chem., Sec. B 1990, 29B, 152.

12. Tsuji, J. Synthesis, 1984, 369.

13. Srikrishna, A.; Reddy, T. J.; Nagaraju, S. Tetrahedron Lett. 1996, 37, 1679.

14. Rodriguez, J.; Dulcere, J.-P. Synthesis 1993, 1177.

15. Stork, G.; Sher, P. M. J. Am. Chem. Soc. 1986, 108, 303. 